\title{
The Implementation of Financial Strategy in Empowering Diversity Education Globally
}

\author{
Muhammad Zuhaili Bin Sabudin \\ Managing Director \\ MUHD ZUHAILI Services \& Quran Centre and MZ Academy - Singapore \\ Email: mzqurancentre@gmail.com
}

\begin{abstract}
In this modern-day world, there are still some children who do not get official or unofficial education due to poverty and so on. Education is the key to freedom from poverty but opportunities are not given in full. The view of "Poverty is an obstacle to education" has become a norm to some people in global world. However with the help of financial strategies, it will have a huge impact on education for every child to be able to defend in achieving basic education in life and to pursue their wishes without making the finances a barrier to them. Therefore, this study is to provide the grassroots and governmental level in empowering education globally with some of the steps that would be proactive in achieving of this goal. The methodology involves interviews with various individual in Singapore on the implementation of the financial strategy in empowering diversity education globally. This is followed by literature research to indentify another group of scholars who argue education financial set up in way that benefits the affluent. It hoped that with the implementation of financial strategy will not only to clear the mindset of poverty as a hinder to education but also to eradicate illiteracy, clear understand and fair system in empowering diversity education globally
\end{abstract}

Keywords: Financial strategies, empower, diversity education

\section{INTRODUCTION}

Education is the most elements in the evolution of the nation. Some people across the world would think that money is an important factor in achieving a better life and forgetting that education is the major factor. Education is the tool which provides people require knowledge, skill, technique, and information and enables them to know their rights and duties toward their family, society, and obviously nation. Hence, without the education we will not explore the new ideas it means we will not able to develop the world because without ideas there is no creativity and without creativity, there is no development. However, education in nowadays becomes costlier such that poor parents of the most talented student cannot even think of getting their wards admitted into such institute. Therefore, the view of "Poverty is an obstacle to education" has become a norm to some people in global world.
In addition to financial strategies in powering education globally, it has been suggested that cultural reasons may have influence the rising levels of inequality. Singapore famously values meritocracy, which is understood here as the belief that individual merit should determine one's success level. First, several have argued that any meritocratic system comes with inherent difficulties. For one, if a meritocracy is to be fair, it requires a system of equalising opportunities and correcting for structural inequalities. Otherwise, factors unrelated to merit will play a significant part in determining outcomes. Secondly, if a society believes in the value of the meritocratic system, but has not taken adequate steps to correct unequal starting points, then successes and failures of individuals, and occasionally of groups of people, may be unjustly ascribed to merit rather than to social advantage or disadvantage. A meritocratic system naturally relies upon education as a primary pathway for social mobility. A fair educational system should, in theory, allow those with the strongest intellectual ability to climb to the top.

Education is often considered to be one of the primary paths available for social mobility. It has been widely noted that Singapore places a strong emphasis on educational attainment, as it ties in well with the ideas of meritocracy: education should allow those with greater intellectual merit to find their way to the top, regardless of where they started. However, while Singapore's education system is touted as being designed to allow anyone with intellectual merit to succeed, many have argued that there are various barriers that hinder certain populations from attaining this success

Therefore a system needs to be developed in order to eradicate the financial problem which can be enhancing to help on the education sector for the individual to have a basic education and foremost the main core of education to develop more stabilised of human civilisation and is able to break the chain of 
poverty. "You can be poor from one generation but you must not be poor in every generation... We are not talking about a one-year or two- year problem. These are the people that require five to 10 years of assistance to get them out of the dark valleys."(Minister for Social and Family Development Chan Chun Sing, 2013.91)

Considering the many challenges that lowincome families face, especially in their desire for greater resilience and advancement, researchers have considered the important role that social capital building plays in their empowerment.

\section{METHOD}

The methodology involves interviews with various individual in Singapore on the implementation of the financial strategy in empowering diversity education globally. This followed literature research on the system that has developed in Singapore and Malaysia tailoring of the possible application to the implementation of the financial strategy in empowering diversity education globally. This is followed by literature research to indentify another group of scholars who argue education financial set up in way that benefits the affluent. For example, Maryam Binte Mohamed Mokhtar, suggests that an "educational

handicap" begins in early education with parents who can afford opting to send their childrento private preschools, which are the dominant providers of early education. Those from the lower income group have to struggle to educate their children before they are enrolled in primary school in order to bring them to the same starting line. As a result, children coming from parents of different income groups have a different level of educational development and capability by the time they enter formal education.

In other case, much of the research on Singapore focuses on inequality rather than absolute poverty. Authors do this for a number of reasons, the most significant being that the incidence of absolute poverty in Singapore is relatively low (and indeed there are some that deny Singapore has any poverty at all in an absolute sense) when compared to most other Asian countries. For years, many observers had argued that Singapore does not have absolute poverty. For instance Kishore Mahbubani, formerly Singapore's Ambassador to the United Nations and current Dean of the Lee Kuan Yew School of Public Policy, wrote in 2001, "There are no homeless, destitute or starving people in Singapore. Poverty has been eradicated, not through an entitlements programme (there are virtually none) but through a unique partnership between the government, corporate citizens, selfhelp groups and

voluntary initiatives."3 There is no doubt, however, that inequality has risen rapidly in

Singapore since the year 2000 (see Chart 1).

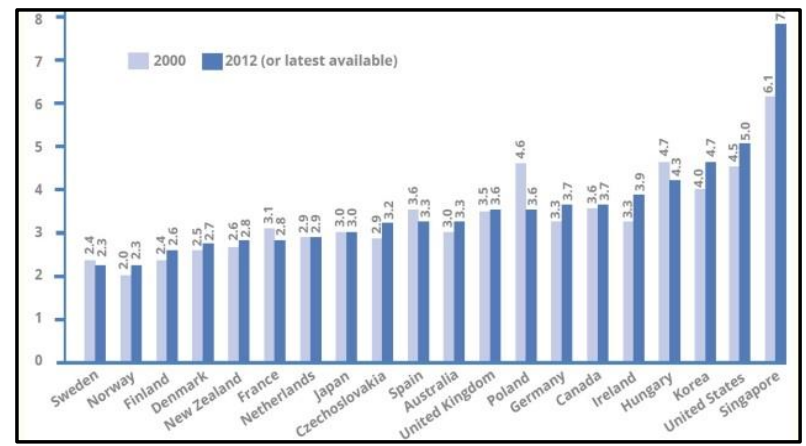

Chart 1: International Comparison of Wage Disparity Source: Hui W. T., "Working Poor in Singapore," FASS Forum on Building an Inclusive Society: Understanding and Empowering the Poor in Singapore

However, the Ministry of Education (MOE) points to evidence that Singapore's education system plays an important role in lifting families out of poverty. For instance, the 2009 Programme for International Student Assessment (PISA) test, which is administered to students in 65 countries, showed that Singapore's less advantaged students were performing better in the reading category than would otherwise be expected. Specifically, about half the students in the bottom socioeconomic quarter earned higher scores in reading than would be expected given their background 4 .

The methodology for this is to develop a system just like the system of Central Provident Funds $(\mathrm{CPF})$ in Singapore or event GST (Goods and Services Tax) in most countries. But this system is what we shall call it as the ETS (Education Tax System) where it plays an important role in the financial strategies.

\section{RESULT}

ETS (Education Tax System) is one of a way for developing nation to promote education to the next level. Indeed, those funding not only to be channel for primary education but even to the higher education programme. 
This ETS System can be another great contribution to a nation education system. Such as Singapore, by the implementation of GST (Goods and Service Tax), it has helped the government to earn an amount of reserved. As quoted from the government website: Even as we save for future crises, we are still benefitting from the reserves now. Contributions from reserves are already the largest contributor to government revenues today. If we did not have our reserves to generate investment returns to spend from, we would have had to more than double personal income tax, or Goods and Services Tax (GST), to raise the same amount of revenue. For instance, every individual from their salary, they have to contribute at least a minimum of $2 \%$ of their salary for ETS. As such, if their basic salary is $\$ 1500$, they will be contributing: $\$ 30$ per month for this system. If in a working population of a country such as Singapore is 3.657 million as in 2017, the total figure will be $\$ 109,710,000$ itself (see Chart:2).

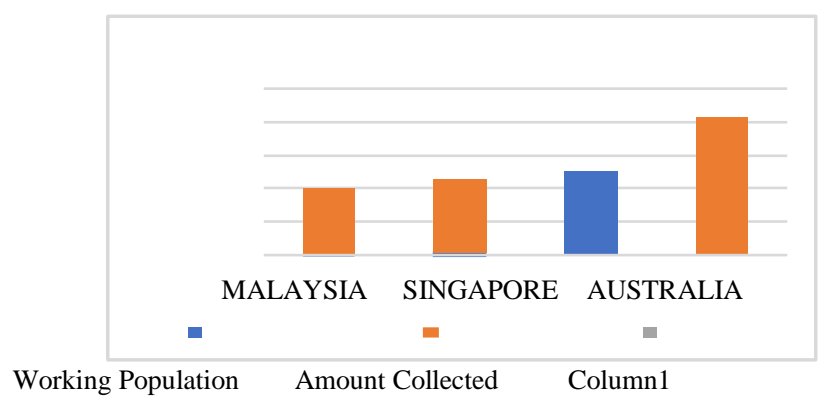

Chart 2: ETS Collection

Based on the chart its shows that Singapore will be able to collect an amount of

$\$ 109,710,00.00, \quad$ Malaysia $\$ 96,331,230.00$ and Australia $\$ 3777,448,000.00$. Therefore, the grand total collected is $\$ 206,041,230.00$ (this figure is in Singapore Dollars) which is equivalent to 151,055,006.95 United States Dollar. This shows clearly that with such financial strategies such as ETS, it will be able to accommodate the entire world population especially within the range of the poorer family that it could be able to eradicate poverty in enhancing education for all. Those funds not only can be distributed for the monthly fees, but there are able to build schools, purchase school buses (for transportation) and other education

infrastructure.

\section{IV: CONCLUSION}

Researcher strongly believes and encourages developing nation to introduce such financial strategy system in empowering diversity education globally. Such system like ETS (Education Tax System) is one of a way for developing nation to promote education to the next level. Indeed, those funding not only to be channel for primary education but even to the higher education programme. Singapore has a significant financial advantage in being able to tap on the contributions from our reserves for spending, instead of using the money to pay interest on debt.

This indicates clearly that with such funding, it will help a nation in the rainy days. However, it is difference concept with ETS. It is an on-going programme monthly which could help future generation and developing nation even the third-world country who indeed in need of education infrastructure development. Not only from the school building, but also from education system, infrastructures, learning material and many more. ETS is another solution which can be implemented with the collaboration between Ministry of Finance \& Ministry of Education as a whole, in fact, with NGOs also it can be part of a great mission to enhance education to the higher level.

Therefore, this study is to provide the grassroots and governmental level in empowering education globally with some of the steps (ETS) that would be pro-active in achieving of this goal. It hoped that with the implementation of financial strategy in empowering diversity education globally. It is hoped that with the implementation of financial strategy will not only to clear the mindset of poverty as a hinder to education but also to eradicate illiteracy, clearly understand and fair system in empowering diversity education globally.

\section{REFERENCES}

A handbook on Inequality, Poverty and Unmet Social Needs in Singapore, 2015.

Amartya Sen, Development as Freedom, (Oxford: Oxford University Press, 1999), as quoted in Felix Naschold,"Why Inequality Matters for Poverty" .

Moore, "Multiracialism and Meritocracy: Singapore's Approach," 353.

PM Lee, "National Day Rally 2013." 